https://doi.org/10.18485/iipe_60nam.2021.ch3

\title{
YUGOSLAVIA, THE MIDDLE EAST AND CREATION OF THE NON-ALIGNED MOVEMENT
}

\begin{abstract}
Aleksandar ŽIVOTIĆ ${ }^{1}$
Abstract: In the years after World War II, the Middle East had a very important place in Yugoslav foreign policy. There are three phases in the evolution of Yugoslav foreign policy in that region. During the first phase which lasted from the end of World War II to 1948, Yugoslavia had certain reservations in relations with this region. The long period which started with the foundation of the Jewish state was marked with the development of close political, military and economic relations with Israel and approach to Egypt after the gradual solution of the problems in mutual relations caused by Yugoslav contacts with banished Egyptian communists. The Egyptian military revolution in 1952 and the beginnings of the orientation of Yugoslav foreign policy towards the creation of a wider movement of non-aligned countries caused Yugoslav decision to develop closer relations with Arab countries. The improvement of relations with Arab countries worsened the contact with Israel. These were the beginning of Yugoslav Middle Eastern policy which was one of the determining characteristics of Yugoslav foreign policy. The Middle Eastern crisis in 1967 left severe consequences on the relations with the Middle East and global international relations. However, the emerging of crisis in the socialist world in 1968 and the confrontations in the Far East, especially because of the war in Vietnam, along with the transition of the problem-solving process of the Middle Eastern crisis in a slower negotiating phase, led to lesser Yugoslav interest in the sanitation of the consequences of the Middle Eastern crisis.
\end{abstract}

Key words: Yugoslavia, Middle East, Egypt, Israel, nonalignment.

${ }^{1}$ Professor at the Faculty of Philosophy, Belgrade University.

E-mail: aleksandar.zivotic@f.bg.ac.rs 


\section{Traditions of Presence in the Middle East Region}

In the years immediately following the end of World War II, the Middle East played a very important role in the complex international relations that were characterised by strong Cold War tensions. A series of low-intensity local Arab-Israeli conflicts, a strong movement to strengthen Arab unity, the creation of a Jewish state, as well as a mutually conditioned process of strengthening anti-colonial movements and withdrawing colonial powers from the Middle East determined the region's special place in global events. Yugoslavia, as a country that went through a process of drastic revolutionary changes during the war and immediately after its end, created its foreign policy by relying on the Soviet Union. The turbulent termination of relations in 1948 caused Yugoslavia to turn towards Western countries. However, since 1953, Yugoslavia was gradually approaching the idea of distancing from the bloc organisation as a permanent foreign policy commitment. In this context, as the region where the interests of two superpowers, the old colonial powers and the young nation-states that aspired to independence, intersected, the Middle East had a special significance for Yugoslav foreign policy. During the period between 1945 and 1956, regarding the Yugoslav state's attitude towards countries and problems in the Middle East, three periods characterised by varying degrees of Yugoslav political, economic and cultural presence in the region and interest in the region's problems could be distinguished, which was directly conditioned by Yugoslav priorities of the foreign policy immediately after the end of the war: resolving the issue of Trieste, defining state borders, complications in relations with Western countries and developing relations with Eastern European countries and the USSR. The first period lasted from 1945 to 1948. This period, which coincides with the period of intensive Sovietization of the Yugoslav state and society, is characterised by the almost complete absence of Yugoslav diplomatic and economic presence in this area and interest in the Middle Eastern problems exclusively within international organisations. This period, which coincided with the period of intensive Sovietization of the Yugoslav state and society, was characterised by the almost complete absence of the Yugoslav diplomatic and economic presence in this area and interest in the problems of the Middle East exclusively within the activities in international organisations. During that period, the first indications that the Yugoslav party leadership was thinking about the need to intensify political and economic relations between Yugoslavia and the countries of the Middle East, and especially with Egypt, could be noticed. Yugoslav envoy in Cairo, Ešref Badnjević, was 
expelled due to disputes over the issue of extradition of war criminals and maintaining intensive ties with banned communist groups, while his successor in office, Shahinpasic, barely escaped a similar fate thanks to his diplomatic skills. Yugoslav homes were closed and activists of emigrant associations were arrested, which affected the overall level of YugoslavEgyptian diplomatic relations. The second period began with the Yugoslav recognition of the newly created state of Israel in 1948 and lasted until the establishment of closer relations with Egypt at the end of 1954. During that period, the Yugoslav-Soviet conflict took place, and then rapprochement with the West and the formation of the Balkan Pact with Greece and Turkey followed. During that period, Yugoslavia developed very close political and economic ties with Israel. At the same time, relations with Egypt were very tense until 1952 due to the actions of Yugoslav political emigration in Egypt and the persecution of Egyptian communists, which the Yugoslav government sharply criticised. A shift in relations happened in 1950 when a special trade agreement was concluded. However, the emerging of crisis in the socialist world in 1968 and the confrontations in the Far East, especially because of the war in Vietnam, along with the transition of the problem-solving process of the Middle Eastern crisis in a slower negotiating phase, led to lesser Yugoslav interest in the sanitation of the consequences of the Middle Eastern crisis (AJ, 837-KPR, I -5-b/UAR).

\section{Yugoslav Opening to the Middle East}

It was only with the change of the regime and the state and social system in Egypt in 1952 that the state of Yugoslav-Egyptian relations began to improve, but by 1954 there were no visible results. The relations with other Arab countries had not yet been established or were in the process of being established. The third period began in late 1954 and lasted until mid-1956. This period was characterised by the maintenance and development of good relations with Israel and the sudden improvement of relations with Egypt after Nasser's takeover of power from General Naguib. During this period, two visits of Yugoslav President Josip Broz Tito to Egypt and the visit of Egyptian President Gamal Abdel Nasser to Yugoslavia took place. The relations between Yugoslavia and Egypt were on the rise after the overthrow of King Farouk. The relations that were strained due to Egyptian tolerance and aiding the anti-communist propaganda of Yugoslav emigration on its territory and the persecution of the Egyptian Communist Party membership with which Yugoslav diplomatic officials maintained close contacts, gradually, although still very heavily, turned into a good and then extremely 
close one. It is not possible to give a valid answer to how the sudden Yugoslav-Egyptian rapprochement took place and who was the creator of such a foreign policy doctrine on the basis of available sources. Nevertheless, the dynamics of that cooperation can be reconstructed, and through the analysis of the events that followed, a number of important questions can be answered. An important role in establishing closer relations between Yugoslavia and Egypt had the young and agile Yugoslav ambassador to Cairo, Marko Nikezić, who managed to come into closer contact with the young Egyptian Prime Minister, Lieutenant Colonel Gamal Abdel Nasser. In a series of long and meaningful conversations, Nasser was interested in Yugoslav revolutionary experiences, economic and social reforms, the development of the armed forces, not hiding his admiration for Yugoslav foreign policy and Josip Broz. In the situation of increasing British pressure regarding the evacuation of British troops from the zone of the Suez Canal, still trying to keep Egypt away from the Soviet Union, he tried to get closer to Yugoslavia in a way, seeing it as a model in the process of creating a new foreign policy direction (DASMIP, PA, 1953, f. 21). On the other hand, Nikezić, assessing the level of Egyptian foreign policy problems and Yugoslav efforts towards a more active policy of non-alignment, paved the way for Yugoslav politics and economy in Egypt, and indirectly in the entire Arab world, which sought to free itself from colonial powers.

The first meeting between Broz and Nasser took place in February 1955 during Broz's return from Burma and India. At the moment when Josip Broz went to visit India and Burma, a visit to Egypt was not planned. Josip Broz's escort only passed through the Suez Canal on its way to the Far East. How and why the original plan was changed is very difficult to determine on the basis of the available sources. It can be assumed that Broz realised in his meeting with Nehru that the policy of the Indian Prime Minister was limited to Asia and that at that time the Middle East was not part of India's foreign policy aspirations, so Egypt simply imposed itself as a regional partner in building foreign policy whose doctrinal postulates were based on the rejection of force and military power as a decisive factor in international relations. Besides, regular reports by envoy Marko Nikezić sent during Josip Broz's visit to India and Burma indicated that Prime Minister Nasser had a strong will to expand ties. This meeting, although it was short, was crucial in the process of Yugoslav-Egyptian rapprochement. Nasser was not hiding his admiration for the Yugoslav president and the Yugoslav social and political system. The personal closeness between Broz and Nasser especially affected interstate relations (AJ, 837-KPR, I-2/4-4). Yugoslav-Egyptian relations improved especially after Josip Broz's visit to Egypt in late 1955 
and early 1956. The cooperation was developing especially through joint actions in international organisations on the issues of national liberation movements of the colonies, equal cooperation between nations and technical assistance to non-developed countries. Egypt supported the Yugoslav candidacy for election to the Security Council in 1955. On 30 July 1955, the Yugoslav mission in Cairo was raised to the level of an embassy. There were some disagreements on Yugoslav relations with Israel, especially in the case of the Yugoslav position on the necessity of free navigation of Israeli ships through the Suez Canal, but this did not, to a greater extent, affect the general level of Yugoslav-Egyptian relations. At the beginning of 1953, the Yugoslav attitude towards the Jerusalem Mufti softened, as a high-ranking Arab League official pointed out the issue as one of the preconditions for the development of Yugoslav-Arab relations. At the beginning of 1953, the Yugoslav attitude towards the Jerusalem Mufti softened, as a high-ranking Arab League official, Hurry, pointed out the issue as one of the preconditions for the development of Yugoslav-Arab relations. The development of good political relations was accompanied by the development of economic relations. In the structure of Yugoslav exports to Egypt, the most important place was occupied by the export of food products. Products of the wood and chemical industries were also exported to a lesser extent. Due to the drought in 1953, the structure of Yugoslav exports changed, and since then the export of wood and chemical industry products has prevailed. Yugoslavia also provided technical assistance to Egypt, especially in the field of the development of hydro construction and fisheries. Initially, Egyptian exports to Yugoslavia were very small in size and had a very unfavourable structure. Yugoslavia imported from Egypt, mainly cotton, and, to a lesser extent, flax, fabric softeners and sea salt. Despite Yugoslav efforts to increase its own exports to the Egyptian market, Egyptian exports to Yugoslavia grew steadily, while Yugoslav exports to Egypt declined rapidly. Since 1953, Egypt and Yugoslavia have established mutual military cooperation. After the regime change in Egypt, relations in the field of cultural cooperation also improved. Yugoslav cultural and artistic ensembles, an exhibition of contemporary Yugoslav painting, as well as the Belgrade Philharmonic Orchestra at the Alexandria Biennale were guests in Egypt. There were also several mutual visits of sports teams. The Egyptian military, economic and cultural delegations that visited Yugoslavia also visited Reis ul Ulema Fejić, the supreme leader of the Yugoslav Muslims. The dynamics of the reception of Egyptian delegations clearly indicated the importance of the role that this religious community played in the period of establishing closer Yugoslav-Egyptian cooperation. 
Undoubtedly, in the period after 1953, the Islamic religious community and its dignitaries played a significant role in establishing close ties between Yugoslavia and the Arab countries, but based on the available source material, the nature of these ties cannot be reconstructed (AJ, 837-KPR, I -5$\mathrm{b} / \mathrm{UAR}$ ). Yugoslavia also developed very good relations with other Arab countries. Very good relations were established with Syria, although there were several incidents in interstate relations in the first post-war years. Namely, several thousand Yugoslav Muslims who fought on the side of Germany during the Second World War arrived in Syria through Italian refugee camps, where some of them were accepted into the Syrian army. Many were given officer ranks in the Syrian army. After 1952, Yugoslavia and Syria developed political, economic and military relations. Several Yugoslav construction companies participated in the construction of the Syrian port of Latakia. Yugoslav special-purpose industry companies exported large quantities of infantry weapons and ammunition to Syria. Immediately after visiting Egypt, a Yugoslav military delegation led by Lieutenant General Radovan Vukanović visited Syria and on that occasion concluded new business arrangements for the export of Yugoslav weapons to Syria. However, very good relations with Syria were damaged by the Syrian-Turkish border conflict, which threatened to escalate into a wider regional conflict because Syria's rival Turkey was in allied relations with Yugoslavia as a member of the Balkan Pact. Yugoslavia's gradual and discreet distancing from the Balkan Pact, and its increasingly pronounced insistence on a policy of non-alignment and the development of relations with Arab countries, had a positive effect on the general level of YugoslavSyrian relations (AJ, 837-KPR, I-5-b). Diplomatic relations with Jordan were established in 1953 only after the death of King Abdullah, who publicly invited Yugoslav political emigrants to immigrate to Jordan without hiding hostility towards the new regime in Yugoslavia. Since then, mutual relations were very good. However, despite the efforts of the two governments, mutual economic exchange remained at a very low annual level. Economic and political relations with Lebanon were also relatively developed, which, due to the character of the Lebanese society and the priorities of the Lebanese foreign policy, did not experience a serious momentum. Diplomatic relations with Iraq did not exist due to Yugoslavia's good relations with Israel. Only after the regime change in Iraq in 1958, the conditions were created for the establishment of Yugoslav-Iraqi relations (AJ, 837-KPR, I-5-b). 


\section{Defining Yugoslav Policy in the Middle East}

Active Yugoslav policy in the Middle East experienced a major manifestation during the Suez Crisis in 1956. The Yugoslav participation in resolving the Suez dispute had multiple and multi-layered aspects. Apart from the political and diplomatic engagement that manifested itself in the daily monitoring of the situation and maintaining contacts with the parties to the conflict and other interested parties, as well as the peace initiative within the United Nations, Yugoslavia also engaged in the military, economic and media activities. Yugoslavia sent its pilots to the Suez Company and thus helped the Egyptian government to temporarily ensure unhindered navigation through the Suez Canal (DASMIP, PA, 1958, f. 3). The Yugoslav media, by unwaveringly representing the views of the Egyptian government, greatly contributed to the affirmation of such a policy in the world. Certainly, the most significant, extensive and longest one was the Yugoslav military engagement within the United Nations peacekeeping force. The Yugoslav detachment within the UNEF carried out tasks in the area of Sinai throughout the whole duration of this peacekeeping mission until 1967. Such a Yugoslav attitude affected the relations between Yugoslavia and Great Britain and France, but also the relations between Yugoslavia and the two superpowers, leaving at the same time consequences on the stability of the Balkan Pact. During the Suez Crisis, the Yugoslav government demonstrated its new foreign policy doctrine, based on the principles of political distancing from the Western and Eastern blocs and the formation of a broader movement of non-aligned countries. By acting in order to resolve a major international conflict such as the Suez Crisis, Yugoslavia was also taking preventive actions to preserve its own national security. At the same time, by sending a contingent to the international peacekeeping force under the auspices of the United Nations, Yugoslavia secured for itself one of the ways of international presence in the region. Also, during the Suez Crisis, Yugoslavia presented the basic principles of its Middle East policy, which fully expressed itself in the following decades, and which was one of the basic tenets of its foreign policy until the collapse of the state in 1991.

\section{A New Culmination of the Middle Eastern Crisis}

The Arab-Israeli conflict did not subside after the wars of 1948 and 1956. Frequent border incidents, Egypt's ban on the navigation of Israeli ships through the Suez Canal, as well as the Arab blockade of the Gulf of Aqaba 
and unresolved border issues made the Middle East conflict permanent and unsolvable. The Israeli government tried to influence the Egyptian government by broader action and by asking for Yugoslav mediation to give up the blockade of the Gulf of Aqaba. Due to the Egyptian rigidity in the positions taken, this initiative did not give results. The constant tension on the Arab-Israeli borders culminated in the spring of 1967. In May 1967, the President of the United Arab Republic, Nasser, requested the withdrawal of the United Nations peacekeeping force from the area of Sinai, so that Egyptian troops could take control of that area. This created the conditions for the beginning of a new war. The Israeli side feared a possible joint Arab attack on Israel. In such conditions, the Israeli state and military leadership decided on preventive military action. The Israeli attack was very violent. It began on 5 June at 7:45 a.m. with a simultaneous Israeli air force attack on ten Egyptian airports. In the first three hours of the war, three air raids were carried out on 19 airports, during which about 300 Egyptian planes were destroyed at the airport stands. The surprise effect was fully achieved. Already on the third day of the war, 7 June, strong Israeli armoured mechanized units reached the Suez Canal. On the same day, the Israeli army took over the old part of Jerusalem and reached the Jordan River. Until the establishment of the armistice through the United Nations on June 10, Israeli troops took control of the entire area of the Golan Heights on the Syrian part of the front. The defeat of the United Arab armies was complete. It is estimated that the Arab armies lost about $70 \%$ of weapons and military equipment worth about one billion dollars, or a total of about 1,000 tanks, while Egypt lost 336, Jordan 29, Syria 60, and Iraq 25 fighter planes. Total human losses were estimated at about 30,000. The Yugoslav government reacted very quickly. The speed of reaction was conditioned not only by close relations with the Arab world, but also by the fact that a Yugoslav detachment within the UNEF was stationed in Sinai, as well as a large number of Yugoslav construction companies, but also by the fact that the Yugoslav People's Army was supplied with oil from the Middle East, which could greatly jeopardise the country's defence capability in a very sensitive foreign policy situation. After several days of negotiations with the Israeli government, a Yugoslav detachment within the UNEF was evacuated through territory controlled by the Israeli army. Yugoslav workers who found themselves in that area were evacuated in the same way. Immediately after the beginning of the war, Yugoslav President Josip Broz Tito issued an official statement on 5 June in which he designated Israel as an aggressor, at the same time appealing to the United Nations to stop the aggression (AJ, 837- KPR, I-5-c). The next day, on 6 June, at a meeting with the president of 
the Federal Executive Council, it was decided to urgently evacuate Yugoslav citizens from the areas directly affected by the war, to strengthen the security of diplomatic missions of the warring parties in Yugoslavia and to issue orders to local Communist League organisations to organise protests. Besides, it was decided to send emergency aid in food and medicine to Arab countries. It was also decided to meet the request sent by the military envoy of the United Arab Republic in Belgrade the day before, asking for the urgent delivery of anti-tank mines, cans of beans and beef and field kitchens. Jugoimport was ordered to determine the methods of delivery of the requested material to the United Arab Republic (AJ, 1967, 837-KPR, I-5-c). The next meeting with the President of the Federal Executive Council was held on 7 June. The meeting was also attended by representatives of the military leadership, Generals Rudi Petovar and Ivan Kukoč. The decision was made to deliver the requested quantities of anti-tank mines and cans of beef and beans to the United Arab Republic as soon as possible, while regarding the delivery of the requested field kitchens, it was found that the Yugoslav People's Army was also lacking them, so it was decided to deliver only a smaller quantity. These funds were delivered to the United Arab Republic by ship within 15 days. Taking into account the urgency of the situation and the purchasing power of the United Arab Republic, it was decided not to raise the issue of payment for goods. At the same meeting, General Petovar stated that the war in the Middle East endangered the supply of fuel to the Yugoslav People's Army which had the reserve for only about 30 days. In addition, he demanded that the government urgently provided funds for the purchase of batteries, tires and spare parts for trucks and ban the export of drugs necessary for the functioning of the army. The Yugoslav military leadership used the existing nervousness of the state leadership caused by the war to provide for the missing funds (AJ, 1967, 837-KPR, I-5-c). In addition, the rapprochement of Yugoslavia and the Arab countries was especially influenced by the Yugoslav decision of 13 June 1967 on the severance of diplomatic relations with Israel. It was very difficult to determine how this decision was made. However, it can be said with certainty that this decision was influenced by a number of factors. Namely, the relations between Yugoslavia and the Arab countries had previously reached a very high level, and any further maintenance of good relations with Israel would leave permanent negative consequences on the relations between Yugoslavia and the Arab world (AJ, 837- KPR, I-5-c). On the other hand, other socialist countries did the same, which also influenced the decision of the Yugoslav state leadership. Also, relations between Yugoslavia and Israel were in a latent crisis since 1956 due to Yugoslavia's 
closeness to Arab countries. Immediately after the severance of mutual diplomatic relations, it was agreed that Austria would represent Yugoslav interests in Israel, and Belgium Israeli interests in Yugoslavia. Immediately after the cease-fire, an emergency shipment of 7 tons of medicine and medical supplies was sent by plane. During the summer of 1967,30,000 tons of corn, 10,000 tons of sugar, 1,000 tons of canned fish, 200 tons of powdered milk, 500 tons of cheese, 500,000 pairs of shoes and a larger quantity of medicines and other food products were delivered (AJ, 837-KPR, I-5-c). At the same time, readiness for the realisation of favourable credit arrangements was expressed. Besides, at the meeting of representatives of the socialist countries in Moscow, Josip Broz tried to provide wider assistance to the United Arab Republic by Eastern European countries. Soviet military planes that transported Soviet military aid to the armies of Arab countries were also allowed to fly over Yugoslav territory. In talks with Soviet representatives, the need for urgent military assistance to Arab countries was emphasised in order to renew their military arsenals and regain the offensive power of their armies as soon as possible. The Vice President of the Republic, Koča Popović, was immediately sent to Cairo and met with President Naser ( ${ }^{2}$ AJ, 837-KPR, I-5-c). He informed Nasser about Yugoslav attitudes, asking for urgent information about Egypt's needs. Also, Popović was especially interested in the attitudes of the Arab world regarding the solution to the crisis. The information was necessary to shape Yugoslav attitudes. On that occasion, in addition to talks on further diplomatic and economic assistance, the modalities of Yugoslav military assistance to the United Arab Republic were also discussed. During the visit of Josip Broz Tito to the United Arab Republic from 10 to 15 August 1967, the head of Broz's military cabinet, General Petar Babić, a man of exceptional Broz's confidence, talked about the possibilities of military assistance to the UAR with Egyptian military officials. A list of priorities was also determined and submitted to the State Secretariat for National Defence through diplomatic channels (AJ, 837-KPR, I-5-c). The delivery of a larger quantity of means of transportation, means of communication, medical supplies, infantry weapons, as well as anti-aircraft and anti-tank weapons was requested. The Yugoslav General Staff immediately compiled a list of funds that it could provide immediately. On that occasion, a visit of a special military delegation of the UAR to Yugoslavia was agreed, which was supposed to prepare a detailed framework of Yugoslav military assistance. The military delegation of the UAR arrived in Belgrade on 3 September. As a part of the protocol, they visited the Secretary of State for National Defence and the President of the Federal Executive Council, while concrete talks 
were held with the delegation of the General Staff led by the Chief of Staff Colonel General Miloš Sumonja. The official talks began on 4 September. They discussed the concretization of the agreement on military assistance, the conclusion of an agreement on the Yugoslav loan to the UAR and the purchase of weapons and military equipment in Yugoslavia. In addition, they discussed scientific-technical cooperation and cooperation in the production of weapons and military equipment, as well as the prospects for further cooperation between the armies. The military delegation of the UAR was especially interested in means of communication, means of transport, anti-armour weapons and anti-aircraft artillery (VA, AJNA, GS-1, k. 10, f. 7). Immediately before their arrival, an agreement was concluded on the Yugoslav delivery of roundels for artillery ammunition (DASMIP, PA, 1967, f. 182). According to the lists of priorities submitted by the Egyptian military authorities to the Yugoslav colleagues, the means that were produced in the factories of the domestic special purpose industry or were in the warehouses of the war reserve were immediately delivered. Either many of the offered means had already been withdrawn from operational use and originated from Western military aid programs to Yugoslavia in the mid-1950s, or it were weapons and military equipment obtained from the Soviet Union immediately after the end of the Second World War. During the talks, the tendency of the Yugoslav military leadership to get rid of a surplus of obsolete weapons and military equipment under the guise of aid to a friendly country was clearly present. Certainly, the most important form of military support to the UAR was the sale of Yugoslav weapons and military equipment under very favourable conditions, which was agreed upon during Josip Broz Tito's visit to Cairo in August 1967. Namely, the Yugoslav government approved a loan to the UAR with a low-interest rate and a longer repayment period for the purchase of Yugoslav products. The loan was repayable with clearing. In this way, the credit policy supported the export of products of the domestic special-purpose industry and indirectly ensured the import of necessary goods from the UAR. The rest of the Yugoslav loan was spent on the purchase of goods in third countries, but through Yugoslav foreign trade companies, which was an additional benefit. Significant quantities of domestic weapons and military equipment and smaller quantities of old Soviet weapons were sold through the credit arrangement (AJ, 837-KPR, I-5-c). Yugoslav military assistance to the UAR and the sale of weapons and military equipment on favourable financial terms were not only of military and economic importance. This was one of the important aspects of Yugoslav foreign policy, especially its segment concerning relations with non-aligned countries. Yugoslav military 
assistance to the UAR was an integral part of widespread and organised political action in the field of comprehensive assistance to Arab countries in order to repair the consequences of the catastrophic political and military defeat suffered during the Third Arab-Israeli War. In addition, it was an introduction to a new phase of mutual political and military relations. The new course of Yugoslav policy in that region was manifested in the first days after the end of the Arab-Israeli conflict in 1967.

\section{Searching for a Solution}

At the initiative of Yugoslavia and a group of non-aligned countries, a special session of the United Nations General Assembly was convened immediately after the end of hostilities. The proposal of a resolution by nonaligned countries to unconditionally condemn Israeli aggression was not adopted at the session as it did not receive the required two-thirds majority, as many non-aligned countries abstained from voting due to the pressure of the United States. However, the proposal received 53 votes, as the representatives of Japan and France also voted for it. Although this action did not yield the expected results, it greatly influenced the definition of the Yugoslav position in the Middle East problem. Appreciating the Yugoslav position in the Arab world and the influence that Josip Broz had with President Nasser, on 28 July and then on 9 August, American President Lyndon Johnson addressed special personal messages to Broz, explaining the US position and asking for assistance in mediating to resolve the crisis (AJ, 837-KPR, I-1/1104). The American position was based on the principles of a quick solution to the crisis while respecting Israeli interests and the recognition of the existence of the state of Israel by the Arabs. Immediately after the crisis subsided, Josip Broz Tito visited the United Arab Republic, Syria and Iraq from 10 to 18 August 1967. The purpose of the visit was to get acquainted with the views of the Arab countries and to present the Yugoslav platform for resolving the Middle East conflict. The Yugoslav platform was based on solving problems within the United Nations bodies with the urgent withdrawal of Israeli troops from the occupied territories while enabling Israeli ships to navigate freely through the Suez Canal. Broz introduced Nasser to the content of Johnson's messages. At the same time, he insisted on representing Arab interests, but tried to convince his interlocutors of the need to recognise the existence of the state of Israel. On the Arab side, Yugoslav views were not fully met with understanding. They insisted on passing a special resolution that would provide for the urgent withdrawal of Israeli military forces, while other disputes would be resolved 
later through direct negotiations. An agreement was reached on the need for wider engagement of non-aligned countries that would come out with their new proposal of the resolution (AJ, 837-KPR, I-5-c). Upon his return to the country, Josip Broz addressed American President Johnson on 24 August. He informed him about the positions of the Arab countries, emphasising that they did not consider the offered framework of the American-Soviet resolution to be a sufficient guarantee of their own security and the withdrawal of Israeli troops. At the same time, he informed him about the Yugoslav platform for resolving the crisis, which would contain five points: withdrawal of all troops from the areas occupied after 4 June 1967: guarantees for security and borders in pre-war form by the Security Council or four great powers until a definitive solution, with the possible stationing of the United Nations peacekeeping force on both sides of the border, free navigation on the Tyrrhenian Sea for all ships until the final decision of the International Court of Justice and navigation on the Suez Canal as before the war (AJ, 837-KPR, I-1/1104). On 19 September, President Johnson responded to Josip Broz by rejecting the Yugoslav proposal as outdated, insisting on accepting the draft US-Soviet resolution. He also firmly stuck to the position that a solution could not be reached without the Arab recognition of Israel and the signing of a peace treaty that would end the state of war that had existed since 1947 (AJ, 837-KPR, I-1/1104). As contacts between Presidents Broz and Johnson did not bring the positions between the United States and the Arab world closer, the Yugoslav leadership decided to take wider action among non-aligned countries in order to reach a solution to the conflict based on the five principles proclaimed in talks with Arab leaders. In addition to non-aligned countries, a special place in that diplomatic initiative was to be given to France, which was the only one among the great Western powers to condemn the Israeli attack on the Arab world. Josip Broz especially appreciated the French position on the issue of the Middle East dispute, and especially the new course of French foreign policy, which was based on distancing from American foreign policy. For that purpose, it was decided that Koča Popović would travel to Paris as a special envoy. Special envoys were also appointed for major non-aligned countries and non-permanent members of the Security Council. President of the Federal Conference of the Socialist Alliance of Working People of Yugoslavia Josip Djerdja travelled to Algeria, Mali and Guinea, Deputy State Secretary for Foreign Affairs Mišo Pavićević to Ethiopia, Tanzania, Uganda and Zambia and member of the Federation Council Svetozar Vukmanović-Tempo to Chile, Mexico, Argentina and Brazil. It was also planned to send several personal messages from President 
Broz to the heads of state and government of all non-aligned countries and permanent and non-permanent members of the Security Council, as well as aide-memoirs of the government of the Socialist Federal Republic of Yugoslavia to other countries (AJ, 837-KPR, I-5-c). The action of the Yugoslav president gave initial results. All his special envoys were received immediately with appropriate importance and treatment. During all contacts, it was stated that Yugoslavia was interested in initiating the process of resolving the Middle East dispute, regardless of different goals and interests. There was a general agreement that the great powers, especially the United States and the Soviet Union, could have a decisive influence on the resolution of the dispute, and that delaying the resolution of the problem was very dangerous. All the interlocutors pointed out the need to pay special attention to the real state of affairs (the balance of power between the Arabs and Israel, the need for recognition of Israel by the Arabs, freedom of navigation). In the international community, the Yugoslav initiative was described as very positive (AJ, 837-KPR, I-5-c). The Yugoslav proposal was supported by U Thant, De Gaulle, Haile Selassie and Indira Gandhi and expressed their readiness to engage, but they did not hide their pessimism regarding the possibility of withdrawing Israeli military forces. They also doubted the readiness of the United States to engage in that direction, so they believed that it was necessary to take wider action and put pressure through the mobilisation of a larger number of countries. Representatives of Chile, Tanzania and Indonesia had similar views. On the same occasion, De Gaulle was particularly critical of the policies of the two superpowers, emphasising the crucial responsibility of the four great powers to resolve the conflict. American President Johnson particularly emphasised Yugoslavia's readiness to launch a discussion, but continued to insist on the views expressed in previous correspondence with Josip Broz. Yugoslav diplomats got the impression that Johnson was very dissatisfied with the rejection of the Soviet-American proposal. The Yugoslav initiative was not supported by a group of socialist countries. In the first reactions, there was even an undisguised tendency to qualify the Yugoslav action as part of the previously made plan at the counselling of the socialist countries in Budapest and Moscow. Only Romanian representatives expressed particular interest in Yugoslav proposals and showed broader understanding and support for such action (AJ, 837-KPR, I-5-c). What brought unrest to Yugoslav diplomacy in a way was the fact that none of the world leaders, except Indira Gandhi, mentioned the role of non-aligned countries in the process of resolving the crisis in the Middle East. It was assessed that there was a collision between the use of the term itself and 
concrete political action that was in line with these principles, which was considered to have found concrete support. Based on the first reactions of a number of world leaders, it was clear that the Yugoslav initiative had achieved a certain effect. This was confirmed by the conclusions of the Yugoslav representative to the United Nations, Anton Vratuša, who emphasised the importance of the Yugoslav initiative but also sublimated the problems that seemed insurmountable in the contacts between the interested parties. Thus, the initial Yugoslav position, which was based on unreserved support for the Arab world, was supplemented by a more detailed elaboration of the platform, which corresponded to the very complicated international situation that arose after the session of the United Nations General Assembly (AJ, 837-KPR, I-5-c). Based on the experiences gained during that initiative, the State Secretariat for Foreign Affairs prepared an extensive study on possible directions for further action of Yugoslav diplomacy. It was assessed that the Yugoslav proposal was accepted as an action that restarted the process of searching for a solution, and these specific aspects of that plan were not considered, so it was thought that further discussions would follow. Further exchange of views within the framework of silent diplomacy was proposed, as it was considered that initiating a wider debate within the United Nations bodies without first securing wider support for the offered platform and harmonization of positions would be absolutely counterproductive. It was considered that in the process of finding a solution, Yugoslav diplomacy should focus on the analysis of reactions to the Yugoslav plan in order to more clearly determine the positions of individual countries in the coming period and the basis for further concrete actions and narrowing differences to create a platform that would be broadly acceptable (AJ, 837-KPR, I-5-c). It was also proposed to continue the dialogue with the Arab world in order to determine the limits to which the Arab world was ready to go to reach a compromise. Also, it was insisted on the dialogue within the United Nations bodies and the expansion of contacts to the whole range of interested countries, which, above all, referred to the Nordic, Western European, Latin American and African countries. It was particularly insisted on the involvement of India in that process as the future chairman of the United Nations Security Council and on the mediating role between the Arab countries and the opposing Western world. Particular emphasis was placed on the belief that any proposal of a new resolution containing a plan or platform for resolving the crisis should be refrained from. The basic idea was therefore to continue negotiations and exchange of opinions in order to find a solution that would have wider support. In later considerations, such a formulation became the 
basis for further action of Yugoslav diplomacy (AJ, 837- KPR, I-5-c). However, the sharp opposition between the conflicting parties, the great powers and the smaller, mostly non-aligned countries over the directions of future actions in order to reach a solution made the dispute more serious and complicated. However, such a Yugoslav effort was often misunderstood by representatives of Arab countries. Thus, the Egyptian ambassador to Yugoslavia, Abuzeid, in a conversation with Yugoslav diplomats, complained about the lack of Yugoslav understanding of the problems of the Arab world. He criticised Yugoslav diplomacy for insisting on political realism (AJ, 837- KPR, I-5-c). It was unacceptable for him to seek a purely political solution. Such a tone in the speeches of the representatives of the Arab countries brought unrest to Yugoslav-Arab relations. The diplomatic action that lasted for several months inside and outside the United Nations bodies culminated in the decision of the Security Council of 22 November 1967. The adopted resolution did not represent a solution to the crisis, but it offered a suitable framework for resolving the crisis. It envisaged the engagement of a special representative of the Secretary-General, who was supposed to enable concrete steps and talks for finding a favourable and acceptable solution. The resolution was based on the accumulation of all submitted proposals and represented a compromise between the various efforts of the directly interested parties. Common to all proposals, including the Yugoslav one, was that the issues of free navigation through the Suez Canal and Palestinian refugees were left for a later stage of the talks. However, what clashed with the Yugoslav proposals was the fact that the adopted resolution did not imply the unconditional withdrawal of Israeli military forces from the occupied territory. At that stage of the talks, a special limiting factor for the Yugoslav side was the fact that Yugoslavia was not a member of the Security Council, which greatly limited its diplomatic room for manoeuvre. Nevertheless, the Yugoslav representatives in the United Nations maintained daily contacts with the representatives of the Arab countries, India and the member states of the Security Council (AJ, 837- KPR, I-5-c). The prevailing opinion in Yugoslav diplomatic circles was that the adopted resolution provided a realistic framework for reaching a solution, but that it was very far from a final solution. Although the Arab countries did not accept the Security Council resolution, their position was strengthened, among other things, thanks to the Yugoslav engagement. This was stated by Egyptian President Nasser in a conversation with Yugoslav Secretary of State for Foreign Affairs Marko Nikezić in Cairo on 28 December 1967. Nasser highly appreciated the Yugoslav military, economic and diplomatic assistance to the Arab world during the crisis. He especially 
emphasized the usefulness of Broz's advice. On the same occasion, Nikezić advised the Egyptian Minister of Foreign Affairs, Riyadh, and maximum flexibility and offered a new joint diplomatic action. In that way, the crisis in mutual relations was overcome very quickly, caused by opposite views on possible directions for resolving the crisis (AJ, 837- KPR, I-5-c). The beginning of 1968 marked a new stage in the process of seeking a solution to the Middle East conflict. The negotiations entered a new and very long phase. The United Nations Special Envoy, Ambassador Jarring, conducted slow negotiations with stakeholders that did not yield more serious results. This type of negotiation was gradually leaving Yugoslavia and its diplomacy aside. During that period, the scope of work of Yugoslav diplomacy on this issue was reduced to constant consultations with representatives of Arab countries (AJ, 837- KPR, I-5-c). Josip Broz reiterated Yugoslav support for Arab countries, especially Egypt, in his personal messages to President Nasser on 26 February 1968 and 31 May of the same year (AJ, 837- KPR, I$1 / 1304$ and I-1/1305). The messages insisted on a further search for a compromise. Despite his influence and Nasser's undisguised admiration for his political greatness, Josip Broz Tito failed to soften extremely rigid Arab attitudes. With the outbreak of the crisis in the socialist world in the spring of 1968 and the strengthening of tensions in the Far East with the escalation of the conflict in Vietnam, the Middle East crisis gradually fell into the background of Yugoslav foreign policy engagement due to certain limitations of Yugoslav foreign policy capacities. The death of Gamal Abdel Nasser, the gradual Arab rapprochement with the Western world, the Yugoslav turn to European politics and the start of Middle East peace talks mediated by the United States led to an accelerated Yugoslav withdrawal from the region with the persistent representation of Arab interests in international forums. Nasser's death and the coming to power of his close associate Sadat, Sadat's "flirtation" with the USSR, and then the United States, conditioned Yugoslavia's distancing from Egypt and orientation towards Iraq with which it developed close military and economic ties. The internal crisis in Yugoslavia, the reduction of its foreign policy capacity and reputation in the world conditioned its reduced interest in that region in the moments before its disintegration. The renewal of diplomatic relations with Israel in 1991 symbolically marked the collapse of Yugoslav pro-Arab Middle East policy. In the years following the conflict with the Soviet Union and its satellites, the Middle East gradually gained an increasingly important place in Yugoslav foreign policy. Leaning on the traditions of the presence of the Kingdom of Serbia and Yugoslavia in that area, under a new ideological spirit in the changed circumstances of international relations, 
Yugoslavia sought to establish closer contacts with Middle Eastern countries on the way to creating a wider movement of non-aligned countries and countries that were not part of the blocs. The character of relations between the Middle Eastern countries themselves, as well as their foreign policy priorities, determined the character of Yugoslav policy in that region, constantly conditioning and tracing the contours of interstate relations.

\section{References}

AJ. Archive of Yugoslavia, 837-KPR, I-5-b/UAR. Reminder on the correspondence of the President of the Republic with President Nasser.

AJ. Archive of Yugoslavia, 837- KPR, I-2/4-4, Transcripts of conversations between Josip Broz Tito and Gamal Abdel Nasser.

AJ. Archive of Yugoslavia, 837-KPR, I-5-b, Inter-Arab Relations and Policy of the Federal People's Republic of Yugoslavia.

AJ. Archive of Yugoslavia, 837-KPR, I -5-b/Iraq, Reminder on YugoslavIraqi Relations.

AJ. Archive of Yugoslavia, 837- KPR, I-5-c, Statement of the President of the Republic on the occasion of the Israeli aggression.

AJ. Archive of Yugoslavia, 837-KPR, I-5-c, Note on the conclusions from the meeting with the President of the SIV on taking measures regarding the latest situation in the Middle East, held on June 6, 1967 at 5.30 pm.

AJ. Archive of Yugoslavia, 837- KPR, I-5-c, Note on the conclusions from the meeting with the President of the SIV on taking measures regarding the latest situation in the Middle East held on June 7, 1967 at $5.30 \mathrm{pm}$.

AJ. Archive of Yugoslavia, 837- KPR, I-5-c, Minutes from the meeting attended by, in addition to President Tito, the following comrades: Edvard Kardelj, Koča Popović, Mika Špiljak, Ivan Gošnjak, Veljko Vlahović, Mijalko Todorović, Milentije Popović, Vladimir Popović, Nikola Ljubicic and Marko Nikezic.

AJ. Archive of Yugoslavia, 837-KPR, I-5-c, Communication on Assistance to Arab Countries.

AJ. Archive of Yugoslavia, 837-KPR, I-5-c, Note on Yugoslav-Egyptian talks.

AJ. Archive of Yugoslavia, 837-KPR, I-1/1104, Message from US President Lyndon Johnson on July 28, 1967 and on August 9.

AJ. Archive of Yugoslavia, 837-KPR, I-1/1104, President Tito's Response to Johnson's Message of August, 24, 1967. 
AJ. Archive of Yugoslavia, 837-KPR, I - 1/1104, Response of US President Lyndon Johnson September , 19, 1967.

AJ. Archive of Yugoslavia, 837-KPR, I - 5 - c, Proposal to send an envoy of the President of the Republic regarding the action to resolve the crisis in the Middle East.

AJ. Archive of Yugoslavia, 837-KPR, I-5-c, Some observations on the first reactions to President Tito's messages.

AJ. Archive of Yugoslavia, 837-KPR, I - 5 - c, Proposal for further activities of the SFRY regarding the situation in the Middle East.

AJ. Archive of Yugoslavia, 837- KPR, I-5-c, Note of the Permanent Representative to the UN, Comrade Anton Vratuša.

AJ. Archive of Yugoslavia, 837- KPR, I-5-c, Note on conversation with UAR Ambassador Abuzeid.

AJ. Archive of Yugoslavia, 837- KPR, I-5-c, Review of the Security Council Decision on the Middle East.

AJ. Archive of Yugoslavia, 837- KPR, I-5-c, Note on the conversation of the State Secretary for Foreign Affairs of the SFRY M. Nikezic with the President of the UAR G.A. Naser, in Cairo on December 27, 1967. Present: Minister of Foreign Affairs of the UAR M. Riad and Ambassador of the SFRY to Cairo D. Lekić.

AJ. Archive of Yugoslavia, 837- KPR, I-5-c, Note on the conversation between the Deputy State Secretary, Comrade M. Pavićević, and the UAR Ambassador, Mr. M. H. Abuzeid on May 23, 1968.

AJ. Archive of Yugoslavia, 837- KPR, I - 1/1304 and I - 1/1305, Message from the President of the Republic Josip Broz Tito to the President of the United Arab Republic Gamal Abdel Nasser.

Bekić, D. (1988). Jugoslavija u Hladnom ratu. Odnosi sa velikim silama 19491955. Zagreb, Globus.

Bogetić, D. (1990). Koreni jugoslovenskog opredeljenja za nesvrstanost. Beograd, ISI.

Bogetić, D. (2000). Jugoslavija i Zapad, 1952-1955. Jugoslovensko približavanje NATO - u. Beograd, Službeni list SRJ.

Bogetić, D. (2006). Nova strategija spoljne politike Jugoslavije 1956-1961. Beograd, ISI.

Bogetić, D. Životić, A. (2010). Jugoslavija i Arapsko -izraelski rat 1967. Beograd, ISI. 
DASMIP, PA. (1953). Report of Marko Nikezić November 11, 1953, f. 21, 416746.

DASMIP. Diplomatic Archive of the Ministry of the Foreign Affairs, PA (1958). strictly confidential, Unification of Syria and Egypt, f. 3, 258.

DASMIP. Diplomatic Archive of the Ministry of the Foreign Affairs, PA (1967). Telegram from the Embassy in Cairo to the DSIP, August 4, 1967, f. 182, 431070.

El Sadat, A. (1979). U potrazi za identitetom. Autobigrafija. Zagreb, Globus.

Гедис, Џ. (2003). Хладни рат. Ми сад знамо. Београд, Clio.

Ginat, R. (1993). The Soviet Union and Egypt 1945-1955. London, Routledge . Jovanović, J. (1990). Jugoslavija i Savet bezbednosti, 1945-1985. Beograd, ISI.

Kyle, K. (2003). Suez. Britain's End of Empire in the Middle East. London, I.B. Tauris.

Lis, L. M. (2003). Održavanje Tita na površini. Sjedinjene Države, Jugoslavija i Hladni rat. Beograd: AGM.

Mićunović, V. (1977). Moskovske godine (1956-1958), Zagreb, Globus.

Petrović, V. (2007). Jugoslavija stupa na Bliski istok. Beograd, ISI.

Животић, А. (2008). Југославија и Суецка криза (1956-1957). Београд, ИНИС.

Животић, А. (2011). Форсирағе песка. Одред ЈНА на Синају (1956-1957). Београд, Одбрана.

VA. Military Archive. AJNA, GS - 1, k. 10, f. 7, r.b. 1, Information on UAR military assistance. 